\title{
Geochemistry of the frost mound's ice in the Sentsa River Valley (Oka plateau, East Sayan Mnt.)
}

\author{
Sergey Alexeev ${ }^{1}$, and Ludmila Alexeeva ${ }^{1,2^{*}}$ \\ ${ }^{1}$ Institute of the Earth's Crust, Siberian Branch, Russian Academy of Sciences, 664033 Irkutsk, Russia \\ ${ }^{2}$ Irkutsk state university, 664003 Irkutsk, Russia
}

\begin{abstract}
The authors have studied the chemical composition of ground ice sampled from the frost mounds located in the unconsolidated sediments of the Sentsa River valley (Oka plateau, Eastern Sayan Mountains) to reconstruct the formation history of these cryogenic creations. Numerous frost mounds of various sizes are mainly composed of clayey silts with interlayers of heavy silts and ice lenses. It is found that the chemical composition of the melt ice sampled from lenses and layers within the frost mounds is $\mathrm{HCO}_{3} \mathrm{Ca}, \mathrm{SO}_{4}-\mathrm{HCO}_{3} \mathrm{Ca}$ and $\mathrm{NH}_{4}-\mathrm{HCO}_{3} \mathrm{Ca}$ with $6.5-15.6$ $\mathrm{mg} / \mathrm{L}$ salinity and $\mathrm{pH}=5.6 \div 6.1$. Whereas, the salinity of the melt textureforming ice sampled from the ice with fractions of enclosing clayey silts was much higher: from 50 up to $792.5 \mathrm{mg} / \mathrm{L}$. River and lake water is ultrafresh $\mathrm{HCO}_{3} \mathrm{Ca}$ with $99-132 \mathrm{mg} / \mathrm{L}$ salinity. The geochemical features of ground ice depend on a water-rock interaction, a presence of organic matter in the unconsolidated sediments and a repeated volcanic activity. The frost mounds are confined to a lacustrine sediments area in the backwater zone that was formed by the Late Pleistocene end moraine. The frost mounds have probably a mixed segregation-injection genesis.
\end{abstract}

\section{Introduction}

Ground ice is an important component of permafrost, including frost mounds. Its chemical composition characterizes the hydrogeochemical environment whilst host rocks and cryogenic formations were developing.

Ground ice in the mineral frost mounds (lithalsa) in particular and in permafrost in general in the Sentsa River Valley, Oka plateau, Easten Sayan Ridge has become a study object quite recently [1-5]. On the basis of ice isotope composition and radiocarbon dating the first fundamental conclusion has been drawn in regards to the Holocene age, the genesis of frost mounds ice cores (lithalsa) and possible ice-formation types. This paper focuses on a definition and analysis of major geochemical peculiarities of ground ice in the frost mounds.

\footnotetext{
*Corresponding author: lalex@crust.irk.ru
} 


\section{Study area}

The Sentsa is the left tributary of the Oka River situated on the Oka plateau at 1800-2500 m a.s.1. [6]. A wide trough valley of the Sentsa River with a 600-800-meter downcut was occupied by a large glacier during the Late Pleistocene. The river actively meanders before the end moraine and forms bayou lakes of various sizes (fig. 1).

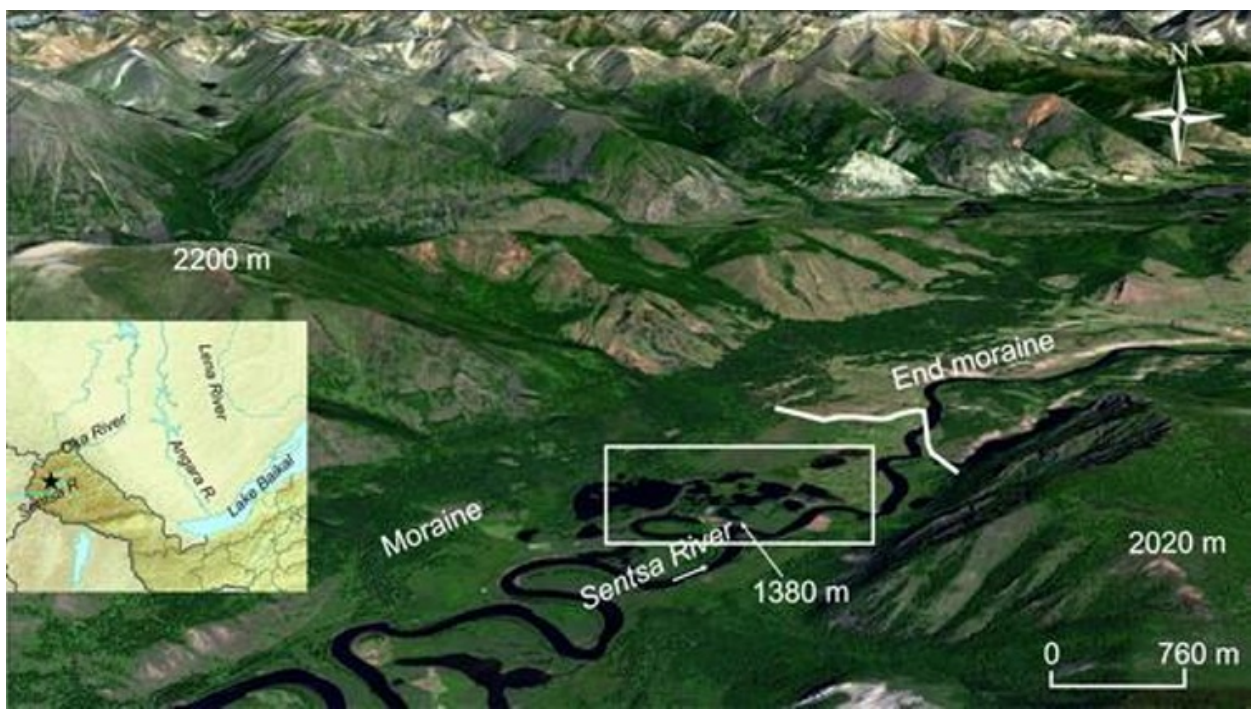

Fig. 1. Sentsa river valley, Oka plateau (GoogleEarth). End moraine boundary (white line) and study region (rectangle and asterisk on the insert-map).

Alluvial, fluvioglacial and lacustrine-alluvial deposits are represented by clayey silts, silts, sands and gravel with rubbles.

The Oka plateau climate is sharply continental. The average mean annual air temperature varies from $-5,6{ }^{\circ} \mathrm{C}$ (at $1372 \mathrm{~m}$ a.s.1.) to $-6,6{ }^{\circ} \mathrm{C}$ (at $2084 \mathrm{~m}$ a.s.1.). The permafrost is continuous on high ridges, high plateaus and watersheds, discontinuous in the midland and sporadic in the river valleys. An average permafrost thickness in the inter-river interfluve area is $140-220 \mathrm{~m}$ [7].

\section{Sampling and analyses}

This article is based on a five-year field and lab researches of frost mounds structure and ice core chemical composition. We examined a total of seven frost mound sections and outcrops in a 1.8-10.7-m high floodplain terrace cliff.

The chemical analyses of ground ice were conducted by the Center for Geodynamics and Geochronology (Institute of the Earth's Crust SB RAS) in Irkutsk. The $\mathrm{K}^{+}, \mathrm{Na}^{+}, \mathrm{Li}^{+}$, $\mathrm{Rb}^{+}, \mathrm{Cs}^{+}, \mathrm{Sr}^{2+}$ concentrations were measured by flame photometry on a SOLAAR M atomic-absorptive spectrophotometer (Thermo Elemental, IN-TERTECH Corporation, USA). $\mathrm{Ca}^{2+}, \mathrm{Mg}^{2+}, \mathrm{Cl}^{-}, \mathrm{HCO}_{3}^{-}$were analysed titrimetrically, $\mathrm{SO}_{4}{ }^{2-}$ and $\mathrm{H}_{4} \mathrm{SiO}_{4}-$ gravimetrically and $\mathrm{NO}_{3}{ }^{-}, \mathrm{NO}_{2}^{-}$and $\mathrm{NH}_{4}$ concentrations were assessed by a colorimetric analysis. 


\section{Ground ice in frost mounds}

One of the largest frost mounds with ice core that we analysed is Se-14-1 (N52 39'79', E99 $29^{\prime} 86^{\prime \prime}$ ). It is $10.7 \mathrm{~m}$ high (along a $45^{\circ}$ inclined plane) and is situated on the Sentsa River's left floodplain terrace (fig. 2 (left)).
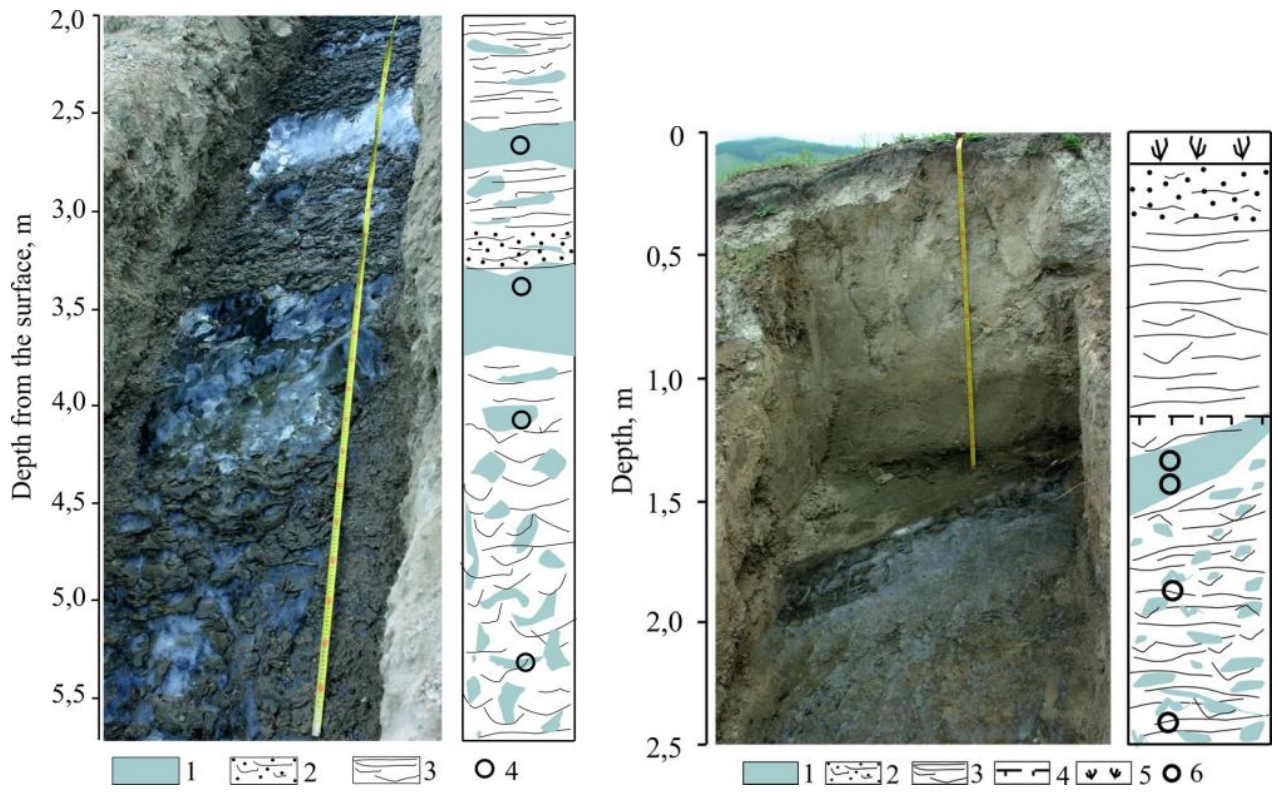

Fig. 2. Frost mound Se-14-1 (left): 1 - ice; 2 - silt; 3 - clayey silt; 4 - point of ice sampling; frost mound Se-16-1 (right): 1 - ice; 2 - silt; 3 - clayey silt; 4 - permafrost table; 5 - vegetation-turf layer; 6 - point of ice sampling.

The mound is constituted of bluish grey clayey silt. Its upper $0.5 \mathrm{~m}$ thick ice lens occurs at $2.35 \mathrm{~m}$. The ice is milky white with rare 1-3 m clayey silt inclusions. The lower lens (4$4.65 \mathrm{~m}$ deep) exhibits transparent ice with numerous round and oval-shaped bubbles and mineral inclusions (fig. 3 a, b). The voluminous iciness the sediments reaches $20-70 \%$. The
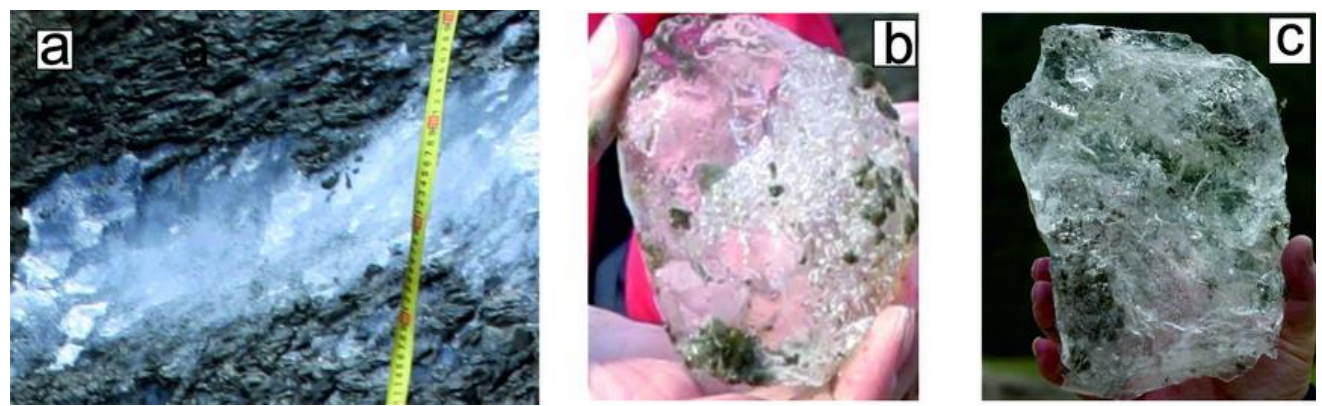

cryostructures are layered, cross-laminated, lenticular, reticulate and basal.

Fig. 3. Ice from frost mounds: a, b - Se-14-1 (4.5 m depth); c - Se-16-1 (1.5 m depth)

The second large frost mound is $\mathrm{Se}-16-1$ (N52 $39.892^{\prime}$, E99 $\left.29.816^{\prime}\right)$. It is $5.8 \mathrm{~m}$ high along a $15^{\circ}$ inclined plane (see fig. 2). A $20-30 \mathrm{~cm}$ thick ice lens was also found in the upper part of the section. 


\section{Chemical composition of ground ice}

The chemical composition of ice from the ice lenses is $\mathrm{HCO}_{3} \mathrm{Ca}$ with salinity 6.5-15.6 $\mathrm{mg} / \mathrm{L}$ and $\mathrm{pH}=5.6-6.1$. The chemical composition of ground ice from melted clayey silts is $\mathrm{HCO}_{3} \mathrm{Ca}$ or Ca-Mg. The salinity varies from 105.7 to $792.5 \mathrm{mg} / \mathrm{L}$ with $\mathrm{pH}$ being 6-7.5 (fig. 4).

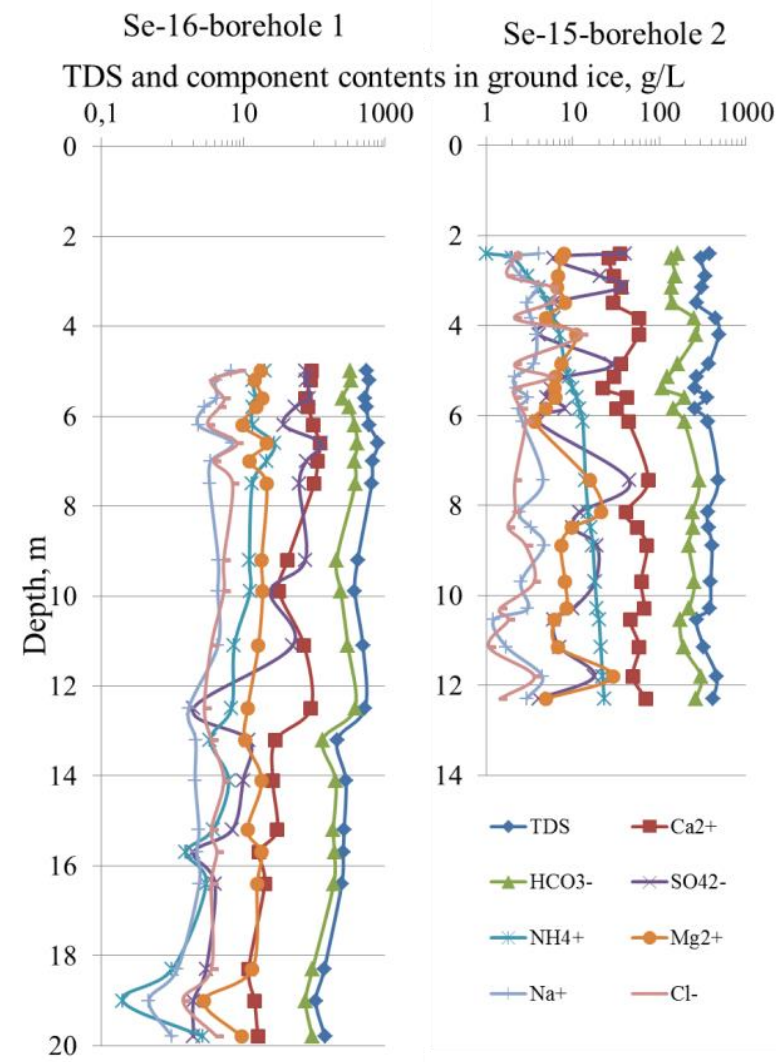

Fig. 4. Chemical composition of ground ice from clayey silts along depth (in the log scale).

Ground ice in clayey silts is more concentrated compared to ice lenses and enriched in $\mathrm{NH}_{4}{ }^{+}$and $\mathrm{SO}_{4}{ }^{2-}$. These components are not typical of the region's surface waters. They could have accumulated in the ice due to water interacting with enclosing lacustrine sediments before their freezing. A natural source of nitrogen-containing compounds in the ice, including ammonium, is an organic substance of animal origin, that is the secretions of living hydrobionts (bacteria, crustaceans and fish), along with lacustrine and lacustrineboggy sediments rich with organic remains.

In addition, a high sulphur content in ground ice could be caused by a sulphurous dioxide and ash emission and acid rains during volcanic eruptions on the Oka plateau $[8,9]$.

\section{Conclusions}

Numerous frost mounds of various sizes are situated on the left floodplain terrace of the Sentsa River in the backwater zone formed by the Late Pleistocene end moraine. They are constituted by interlayering lacustrine-alluvial ice clayey silts, silts and pure ice lenses.

Frost mound ground ice is ultra fresh and fresh. The ice salinity from ice lenses and ground interlayers is $6.5-15.6 \mathrm{mg} / \mathrm{L}$, which is higher in structure-forming ice by one order of magnitude. 
The frost mounds have a $\mathrm{HCO}_{3}, \mathrm{SO}_{4}-\mathrm{HCO}_{3}$ and $\mathrm{NH}_{4}-\mathrm{HCO}_{3} \mathrm{Ca}$ composition. This specific character of ground ice geochemistry results from a water-rock interaction, presence of organic substances in unconsolidated sediments and, supposedly, repeated volcanism in the late Pleistocene-Holocene, which increased a sulfate content in the surface and ground waters.

This study was financially supported by the Russian Foundation for Basic Research, grant N 16-0500115. The authors thank A.A. Rybchenko, A.A. Svetkakov, and A.V. Dubynin for assistance with field works.

\section{References}

1. S.V. Alexeev, S.G. Arzhannikov, L.P. Alexeeva, Yu.K. Vasil'chuk. Proc. of the Intern. Conf. Tyumen: Epoch, (2015)

2. L.P. Alexeeva, S.V. Alexeev, Yu.K. Vasil'chuk, E.A. Kozyreva, A.A. Svetlakov. Advan. in cur. nat. scien., 3 (2016)

3. Yu.K. Vasil'chuk, S.V. Alexeev, S.G. Arzhannikov, L.P. Alexeeva N.A. Budantseva, Yu N. Chizhova, A.C. Vasilchuk, E.A. Kozyreva, A.A. Rybchenko, A.A. Svetlakov E. Cryos., XIX (2) (2015)

4. Yu.K. Vasil'chuk, S.V. Alexeev, S.G. Arzhannikov, L.P. Alexeeva, N.A. Budantseva, Ju N. Chizhova, A.C. Vasilchuk. Perm. and Perig. Pr., 27 (3) (2016)

5. V.B. Sochava. Atlas of Transbaikalia (Buryat ASSR and Chita region) (1967)

6. S.G. Arzhannikov, R. Broshe, M. Zholive, A.V. Arzhannikova. Geol. and Geoph., 56 (11) (2015)

7. Hydrogeology of the USSR. Buryat ASSR (1970)

8. S.V. Rasskazov, N.A. Logachev, I.S. Brandt, S.B. Brandt., A.V. Ivanov Geochronology and geodynamics of Late Cenozoic (South Siberia - South and East Asia) (2000)

9. A.V. Ivanov, S.G. Arzhannikov, E.I. Demonterova., A.V. Arzhannikova, L.A. Orlova. Bul. of Volc., 73 (2011) 